\section{Revue de l'Université de Moncton}

Revue de l’Université

\section{Soil and Sublimity in Childe Harold's Pilgrimage}

\title{
Michael R. Edson
}

Numéro hors-série, 2005

Des actes sélectionnés du $30^{\mathrm{e}}$ Congrès international sur Byron "Byron and The Romantic Sublime"

URI : https://id.erudit.org/iderudit/014356ar

DOI : https://doi.org/10.7202/014356ar

Aller au sommaire du numéro

\section{Éditeur(s)}

Revue de l'Université de Moncton

ISSN

0316-6368 (imprimé)

1712-2139 (numérique)

Découvrir la revue

Citer cet article

Edson, M. R. (2005). Soil and Sublimity in Childe Harold's Pilgrimage. Revue de l'Université de Moncton, 177-187. https://doi.org/10.7202/014356ar

\section{Résumé de l'article}

Cet article commence par une brève description des moyens par lesquels la terminologie et les conventions régissant la description de paysages sublimes informent le discours géologique de la fin du dix-huitième et du début du dix-neuvième siècle, tel qu'exemplifié par Theory of the Earth de James Hutton (1789) et Essays on the Theory of the Earth de Georges Cuvier (1813). Je ferai ensuite valoir que les réflexions de Byron sur l'érosion graduelle mais inévitable des empires et des cultures dans Childe Harold's Pilgrimage et The Age of Bronze montrent une perspective (in)formée par la géologie, et que le sublime, dans ces poèmes, est produit par la rencontre avec les processus historiques et le temps géologique, qui sont vastes, auto-anéantissants et inimaginables. Dans ces poèmes, non seulement la description par Byron de l'être humain fait d'argile renvoie aux origines et au destin ultime de notre substance corporelle, elle associe l'humain (le culturel) à la strate érodée et soulevée par les forces naturelles et incontenables. Dans ces poèmes, les lieux physiques deviennent temporels; les ruines, souvent associées au pittoresque, deviennent sublimes. Elles ne sont pas de terrifiants symboles du transitoire culturel ou de l'insignifiance de l'être humain, mais plutôt des affleurements minéralisés et exposés temporairement dans lesquels le sujet percevant (le narrateur, puis le lecteur par la suite) peut lire le passage du temps et contempler l'éventualité horrifiante de sa propre désintégration et de sa mort.
Ce document est protégé par la loi sur le droit d'auteur. L’utilisation des services d’Érudit (y compris la reproduction) est assujettie à sa politique d'utilisation que vous pouvez consulter en ligne.

https://apropos.erudit.org/fr/usagers/politique-dutilisation/ 
Revue de l'Université de Moncton, Numéro hors série, 2005, p. 177-187.

SOIL AND SUBLIMITY IN CHILDE HAROLD 'S PILGRIMAGE

\author{
Michael R. Edson \\ University of Delaware \\ United States
}

\title{
Résumé
}

Cet article commence par une brève description des moyens par lesquels la terminologie et les conventions régissant la description de paysages sublimes informent le discours géologique de la fin du dix-huitième et du début du dix-neuvième siècle, tel qu'exemplifié par Theory of the Earth de James Hutton (1789) et Essays on the Theory of the Earth de Georges Cuvier (1813). Je ferai ensuite valoir que les réflexions de Byron sur l'érosion graduelle mais inévitable des empires et des cultures dans Childe Harold's Pilgrimage et The Age of Bronze montrent une perspective (in)formée par la géologie, et que le sublime, dans ces poèmes, est produit par la rencontre avec les processus historiques et le temps géologique, qui sont vastes, autoanéantissants et inimaginables. Dans ces poèmes, non seulement la description par Byron de l'être humain fait d'argile renvoie aux origines et au destin ultime de notre substance corporelle, elle associe l'humain (le culturel) à la strate érodée et soulevée par les forces naturelles et incontenables. Dans ces poèmes, les lieux physiques deviennent temporels; les ruines, souvent associées au pittoresque, deviennent sublimes. Elles ne sont pas de terrifiants symboles du transitoire culturel ou de l'insignifiance de l'être humain, mais plutôt des affleurements minéralisés et exposés temporairement dans lesquels le sujet percevant (le narrateur, puis le lecteur par la suite) peut lire le passage du temps et contempler l'éventualité horrifiante de sa propre désintégration et de sa mort. 
A passage early in canto 1 of Childe Harold's Pilgrimage illustrates the difficulty of distinguishing the sublime from the mock-sublime in Byron's landscapes:

The horrid crags, by toppling convent crown'd, The cork-trees hoar that clothe the shaggy steep, The mountain-moss by scorching skies imbrown'd, The sunken glen, whose sunless shrubs must weep,

The tender azure of the unruffled deep, The orange tints that gild the greenest bough, The torrents that from cliff to valley leap, The vine on high, the willow branch below, Mix'd in one mighty scene, with varied beauty glow.

(CHP 1. 19)

The oft-cited account of Cintra exemplifies the problem that Byron's self-conscious narrator poses to readers who seek moments of sublime self-loss. If the stanza verbally replicates visual overload, then its alliterative and adjectival excesses also appear to gesture sardonically at clichéd landscape poetry. The realistic detail, "cork-trees," presents a further interpretive challenge. Though appropriate to a loco-descriptive poem for an English audience unschooled in the flora of Portugal, this botanic particular also undercuts the sublime's requisite obscurity. Read against the exclamation of sublime inadequacy proceeding it, "Ah me! what hand can pencil guide, or pen, / To follow half on which the eye dilates" (18), this stanza's more than adequate description appears to be a further irony. Yet whether these lines satirize the artificialities of sublime description or seriously attempt to represent the unrepresentable remains uncertain.

Questions about its manner aside, the matter of the above stanza is recognizably sublime: mountains are the sublime natural objects par excellence. For Romantic poets such as Goethe and Wordsworth, craggy mountains and massive rocks were markers of superhuman permanence, formed of the original material of the earth. ${ }^{1}$ Their poems are littered with sublime stones. As Noah Heringman has argued, rocks were the "preferred objects" of geological and poetical description during the 
Romantic period. ${ }^{2}$ However, by collapsing the diversity of the "earth's material" (6) into the single category of rock, Heringman overlooks a countertrend in Romantic poetry that views soil as a distinct geological and aesthetic object. In cantos 1 and 2 of Byron's Childe Harold's Pilgrimage shifting soil, not static stone, arrests the narrator's eye. Thus I will argue that the monumental wrecks of Greece in canto 2 are not just sublime insofar as they are ancient, enduring rocks. The ruins at Athens are also sublime because they are eroded emblems of eternal change, the stony equivalents of the sublimely fluxing ocean of canto 4 . By attending closely to rocks, dust, and dirt in Childe Harold's Pilgrimage, I hope to offer new insights into Byron's aesthetics.

When Byron published the early cantos of Childe Harold's Pilgrimage in 1812, theorizing about the sublime had been proceeding vigorously for nearly a century. Geology, on the other hand, was still relatively new. Earth science had broken with mineralogy during the 1790s (Porter 1439); the Geological Society of London had been founded in 1807; and the heading "geology" had appeared in the Encyclopedia Britannica as recently as 1810 (202). Even so, the young science shared several concerns with its older aesthetic counterpart. Sublime landforms mountains, volcanoes, caves - doubled as the objects of geological investigation. As geologist Humphry Davy noted in 1805, "the views of the geologist are directed to the same grand objects as those of the poet and the painter" (207). In addition, the descriptive idioms of geology and sublimity were largely interchangeable. Consider, for example, geologist George Greenough's 1805 account of Fingal's Cave:

We walked on the tops of the pillars about 100 yards before we reached Fingal's cave - the first view of it from without is such as it is utterly impossible for me either to describe or to forget. It completely deprived me for a time both of speech and of breath. . . . The pillars are close to each other, and in this respect differ materially from such as are formed by starch, 
clay and other substances ... the number of their sides varies ... from three to eight. (qtd. in Rudwick 126)

Moving between an empirical idiolect of measurements ("100 yards") and components ("starch, clay"), and an aesthetic vocabulary of affective response ("deprived . . . of speech and of breath") and failed representation ("impossible ... to describe"), Greenough's journal entry exhibits the same blend of capable expression and self-declared inexpressibility that characterizes Byron's description of Cintra.

Early geology and sublime aesthetics, of course, also had their differences. Notwithstanding the reservations of such fiercely Baconian geologizers as Greenough, the operations of early earth science were synecdochic, moving from local phenomena to universal theories, from visible parts to an invisible whole. In contrast, sublime aesthetics might be said to articulate an opposite cultural impulse: to overlook knowable particulars for an unknowable entirety, thereby trading feelings of scientific mastery for troubling sensations of insignificance and limitation. But the parts and particulars of geology — those minerals and soils composing mountains, volcanoes, and boulders - were apparently sublime as well. In A Philosophical Enquiry into the Origin of our Ideas of the Sublime and Beautiful, Edmund Burke reflected that "littleness is in some measure sublime," because the "excessively small" can as much "escape the . . . sense" as the expansive (128-9). Decades later, Greenough, observing the rocks along the Scottish coast, also finds "grandeur in . . . composition" (qtd. in Rudwick 128). Davy goes even further, declaring that "the sublimity of the great forms of nature" is not diminished but rather "enhanced by the contemplation of their order" (200). If its tiny mineral components were as grand as the boulder itself, then soil, the smallest, most fragile, and most ubiquitous of the earth's materials, could also be sublime.

Yet the extent of Byron's acquaintance with such contemporary geological thought is difficult to ascertain. As Ralph O'Connor has argued, Cain and portions of Don Juan bear the unmistakable stamp of the theories of Georges Cuvier, whose Essay on the Theory of the Earth appeared in English in 1813. ${ }^{3}$ Prior to Cuvier, however, influences are not as easily identified. Byron might have encountered geological theory in 
the pages of the Edinburgh Review ${ }^{4}$ or his other non-scientific reading, including Erasmus Darwin's The Botanic Garden. ${ }^{5}$ Another possible source for Byron's geological knowledge was Humphry Davy. A founding member of the Geological Society of London, Davy delivered a series of public lectures on geology in 1805 and in 1811. As Byron's correspondence suggests, the poet seems to have dined with Davy during $1813,{ }^{6}$ yet these evenings spent together, if containing any geological discussion, came too late to have any impact on Childe Harold's Pilgrimage cantos 1 and 2 (published March 1812). In any case, the tropes of early geology, as we will see, appealed to Byron, and thanks in part to Davy's public lectures, geological ideas were part of the larger cultural milieu from which Byron could freely borrow. Emphasizing human insignificance - or, as Byron might say, "littleness" - in the face of inexorable erosion, uplifting, and subduction, geology offered Byron a variety of images by which to articulate his view of the human condition. Sedimentation and erosion become metaphors for the collapse of empires and human death in Childe Harold cantos 1 and 2.

\section{III}

If not all geological objects were of equal interest to seekers of the sublime, then Byron's narrator pays attention to what at first seems the least sublime of geological objects - soil. Just as his description of Cintra moves from high to low, mountain to valley, so the narrator's depressiveidealist eye glances up at rocks throughout cantos 1 and 2 only to dwell, visually as well as intellectually, on the soil below. Such a viewing practice is at odds with that inscribed within sublime landscape paintings from the period. As James A. W. Heffernan has noted, Romantic painters minimized the foreground and used lower angles of view, thereby "forcing" the viewer's eye "to look up" at towering trees and threatening cliffs (134). While Heffernan does not use the word "sublime" to describe this effect, the enforced upward movement of the eye is a well-known part of the visual response to a sublime object. But the eye of Byron's narrator frequently takes a high angle, and moves downwards across the landscape rather than upwards. Whatever its sublimity when viewed from below, Cintra nonetheless affords "loftier rocks" (CHP 1. 20), a convenient 
platform from which the narrator, the reader, and Harold look down on "the vale beneath" (22). This is not to say, of course, that the poem does not feature its share of sublime mountains viewed from below. Cintra, Parnassus (CHP 1. 60), and Zitza (CHP 2. 48) all receive ample descriptions that emphasize their sublime verticality. Yet more often mountains are literally passed over by the poem, just as Childe Harold himself "pass'd o'er many a mount sublime" (CHP 2. 46). In terms of line count, Byron's poem simply shows more interest in describing the vertiginous details of the cities of Lisbon (CHP 1. 16), Mafra (29), Seville (45-8), Cadiz (71-80), Tepelini (CHP 2. 55-66), Constantinople (77-8), and Stamboul (79), and also the (battle)fields of Talavera (CHP 1. 38-42), Albuera (43), Andalucia (49-50), Barossa (90), and Marathon (CHP 2. 89$90)$, than it does in delineating "mount[s] sublime."

What might the narrator find so interesting about valleys, fields, and cities? Despite the wasting human agencies elsewhere on the Peninsula, the narrator consistently experiences soil in terms of fertility and abundance, for in Portugal "Fruits of fragrance blush on every tree" (CHP 1. 15). Description of the overtly rocky, in contrast, is notably spare, and the few modifying adjectives only further a sense of physical desolation. Pindus is simply "bleak" (CHP 2. 47), Albania's hills are "stern," and Suli's rocks "dark" (42). Despite the soil's association with natural abundance, however, the poem also links it with mortality, human and otherwise. In Cadiz, the narrator recounts how the bull, entering the arena, "spurns, with sounding foot, / The sand" (CHP 1. 75) only later, in death, to "sink" upon it (78). Likewise, humanity, though "Bound to the earth," nevertheless "lifts [its] eye to heaven," pining for immortality (CHP 2. 4). Images linking soil and natural prosperity intermix with images associating death with dirt. "[W]ild flowers" and "giant weeds" sprout from the "deserted" human dwellings at Cintra (CHP 1. 22-3). Consider, also, the following passage:

Dusky and huge, enlarging on the sight,

Nature's volcanic amphitheatre,

Chimaera's alps extend from left to right:

Beneath, a living valley seems to stir;

Flocks play, trees wave, streams flow.

(CHP 2. 51) 
Moving, once again, from mountain to valley, rock to soil, the narrator emphasizes through redundancy ("living valley") and active verbs ("play," "wave," "flow") the variety and life of the valley in contrast to Cithaeron's monolithic barrenness. Yet soil is also a site of death, as is apparent from the various fields-cum-battlefields described throughout the poem. Unlike stony mountains, the earthy plains are the places where both the ontological distinction between organic and inorganic fails to signify and the endless cycle of growth and decay is made most visible. If rocks are sublime by virtue of their superhuman endurance, then soil is also sublime because it suggests the inevitability of decay for rock and flesh alike.

\section{IV}

Neither Harold nor the narrator is a geologist, but their interest in soil proves important nonetheless. For Byron, who hailed the creative material "fiery dust" (DJ 2. 212) and likened the human condition to a struggle between immortal spark and mortal clay, soil offered a fertile metaphor. Byron no doubt made the commonsense observation that valleys and fields, formed by erosion and sedimentation, were habitable, human spaces, the geographical sites of cultivation and Kultur. To that extent, clay was also the proper metaphor for humankind - fragile, transitory, endlessly changing. Byron recognized the value of "soil" as a political metaphor as well. Robert Southey had exploited it, years earlier, in Wat Tyler (1794): "Ye feel alike the infirmities of nature; / And at last moulder into common clay / Why then these vain distinctions?" (3. lines 239-41). But in Childe Harold's Pilgimage, Byron's narrator radically extends Southey's geological analogy, erasing the line between the human and the geological altogether. Thus friend and enemy, human and animal, human "clay" and earthly clay will intermix come canto 3 in the sandy soil at Waterloo: "The earth is covered thick with other clay, / Which her own clay shall cover, heaped and pent, / Rider and horse, - friend, foe, - in one red burial blent" (28). Extending the metaphor to its logical conclusion, Byron figures human death as just another deposition of sediment overlaid by subsequent stratifications.

Throughout cantos 1 and 2 the narratives of human history and geological process are "blent" just as human and non-human sediments 
mix at Waterloo. Often this blurring of the line between flesh and soil occurs at the level of the single word. The narrator's use of the verbs "fall" and "sink" offers one example. To the extent that he uses them to articulate human death at Albuera, the national decline of Greece, and the crumbling of the physical structures at the Acropolis, "fall" and "sink" erode distinctions between human death, cultural collapse, and geological decay. Even religion is not spared from this geological cycle of rise and fall: "religions take their turn: / 'Twas Jove's — 'tis Mahomet's - and other creeds / Will rise with other years" (CHP 2. 3). The poem's "geologizing" of humanity — that is to say, its viewing human culture as subject to erosion and sedimentation — is also aided by the poem's frequent reminders concerning the similar destination of human flesh and stone: sand, dust, and dirt. The fleshy bull, in canto 1 "sinks upon the sand" just as the stony Grecian temple, in canto 2, "commingl[es] slowly with heroic earth" (85).

Like "fall" and "sink," the oft-used adjective "mouldering" also participates in the poem's eliding of the line between flesh and stone. Signifying eroded rock and plant-matter as well as decayed human bodies in its noun form, "moulder" accomplishes linguistically what Byron's elaborate metaphors only suggest - that human and mineral decay are analogous processes. Such metaphorical mixing of flesh and stone is visible throughout the poem, as when the narrator likens the human skull to a "lonely tower" (CHP 2. 6), or when Lord Elgin, "Cold as the crags upon his native coast, / His mind as barren and his heart as hard" (12), takes on the stoniness of Scotland's geology. But "moulder" not only denotes the gradual process of decay signified by "fall" and "sink;" it also emphasizes the centrality of soil — of mould — as the geographical destination and geological end-product of decaying flesh and rock alike. Soil thus becomes an emblem, its presence a testament to the barely perceptible but nonetheless inexorable processes of decay. Byron's narrator articulates human decay in terms of geological process, as both gradual subduction - "nations, tongues, and worlds must sink beneath the stroke" (53) — and oceanic erosion — "the pleasaunces on earth . . . Swept into wrecks anon by Time's ungentle tide" (CHP 1.23). 
In the first note to canto 2, Byron responds to the rocky remnants of Greece with thoughts of human fragility and insignificance: "[N]ever did the littleness of man . . . appear more conspicuous in the record of what Athens was, and the certainty of what she now is" (CPW 2: 189). When Byron asserts that humanity's "littleness" is most apparent in "what Athens was" and "what she is now," he might appear to endorse the usual sublime of duration, suggesting that the past and continued existence of Greece's stony monuments prompts his sublime feeling of fleshy insignificance. But Byron's experience of "littleness" may as much stem from his juxtaposing Greece's past with Greece's present, and thus also recognizing a process of decay. Neither the staying power of Greece's cultural achievement nor the endurance of its material fragments excites Byron's sublime sensations of "littleness." Rather, his awareness that even the stones of Greece waste away inspires a sublime sense of human transience.

Byron's awareness of ongoing decline also emerges in his narrator's reactions to the monumental fragments of Greece. Byron's juxtaposition of Athens' imagined past and present state parallels the narrator's double vision in the poem, evident in his paradoxical apostrophe at canto 2 stanza 73: "Fair Greece! sad relic of departed worth! / Immortal, though no more! though fallen, great!" Though the narrator struggles to articulate a process of decay, he cannot move beyond the available vocabulary of static states ("Immortal," "no more," "fallen," "great"). Participial constructions in his earlier opening meditation on Greece further the impression that the narrator is acutely aware of the dissolution going on around him. "[M]ouldering tower" (2), "saddening shrine" (11), and other phrases situate Byron's narrator at a point in an ongoing degradation rather than at a static end-state of ruin. The narrator employs an image of rock eroding into soil to capture the architectural and cultural disintegration of Greece: "Thy fanes, thy temples to thy surface bow, / Commingling slowly with heroic earth" (85), asserting a line later the inevitability of universal decay, "So perish monuments of mortal birth, / So perish all in turn, save well-recorded Worth." 
Yet it seems that not all monuments perish. After the semi-colon linking stanzas 85 and 86, Byron's narrator immediately adjusts his previous statement, reasserting the sublime of duration: "Save where some solitary column mourns / Above its prostrate brethren of the cave; / Save where Tritonia's airy shrine adorns / Colonna's cliff . . ." Here the sublime sense that even "granite moulders" - a rock, according to Davy, "little liable to decomposition and decay" (208) - is qualified. Thus two different notions of sublimity, however seemingly incompatible, coexist in canto 2 of Child Harold's Pilgrimage: the earthy sublime of endless wasting and the stony sublime of heroic endurance. Ubiquitous, minute, and changeable, soil displays none of the massiveness and permanence attributed to rocks by theorists of the sublime since Edmund Burke. Even so, the poem's interest in clay, in both its human and non-human varieties, points the way to an alternative sublime that turns not on a binary division of stone and flesh, but rather on recognition of their fundamental similarity. Although the narrator and Harold contemplate their share of sublime stones in Childe Harold's Pilgrimage cantos 1 and 2, readers should also recognize that they spend equal if not more time "gaz[ing] complacent on congenial earth" (CHP 2. 92).

\section{Works Cited}

Burke, Edmund. A Philosophical Enquiry into the Origin of our Ideas of the Sublime and Beautiful. 1759. New York: Garland, 1971.

Byron, Lord George Gordon. The Complete Poetical Works. Ed. Jerome J. McGann. 7 vols. Oxford: Clarendon, 1980-1993.

Davy, Humphry. The Collected Works of Sir Humphry Davy. Ed. John Davy. Vol. 8. London: 1840.

Heffernan, James A. W. The Re-Creation of Landscape. Hanover, NH and London: UP of New England, 1984.

Heringman, Noah. Romantic Rocks, Aesthetic Geology. Ithaca and London: Cornell UP, 2004.

O'Connor, Ralph. "Mammoths and Maggots: Byron and the Geology of Cuvier." Romanticism 5.1 (1999): 26-42. 
Porter, Roy. The Making of Geology: Earth Science in Britain 1660-1815. Cambridge: Cambridge UP, 1977.

Rudwick, M. J. S. "Hutton and Werner Compared: George Greenough's Geological Tour of Scotland in 1805." The British Journal for the History of Science 1.2 (1962): 117-135.

Southey, Robert. "Wat Tyler: A Dramatic Poem." 1817. Ed. Matt Hill. Romantic Circles. Online. Internet. 15 July 2004. Available $<\mathrm{http}: / /$ www.rc.umd.edu/editions/wattyler/>.

1 In her discussion of his 1784 essay “On Granite," Heather I. Sullivan describes Goethe's conviction that granite was "the original material out of which the oldest and highest mountains were formed" (344). An advocate of Abraham Werner's geological system, Goethe believed mountains were the first landforms to precipitate from the waters of an ancient deluge, and that granite was, then, the foundation of all other rocks (344-347). Traversing mountains and collecting stones was thus to bring oneself into contact with the earth's original material and its eternal processes, thereby transcending fleshy limitation (343). See "Collecting the Rocks of Time: Goethe, the Romantics and Early Geology," European Romantic Review 10.2 (1999): 341370. Wordsworth's attitude towards mountains is expressed in the fragment, "The Sublime and the Beautiful," in which he invokes "that cluster of Mountains at the Head of Windermere" to illustrate the three aspects of sublimity: "a sense of individual form or forms; a sense of duration; and a sense of power" (349-350). See Appendix III, The Prose Works of William Wordsworth, ed. W. J. B. Owen and Jane Worthington Smyser, vol. 2 (Oxford: Clarendon, 1974).

2 In addition to Heringman's work, other studies of Romantic poetry and geology include John Wyatt, Wordsworth and the Geologists (Cambridge: Cambridge UP, 1995) and Anne D. Wallace, "Picturesque Fossils, Sublime Geology? The Crisis of Authority in Charlotte Smith's Beachy Head," European Romantic Review 13 (2002): 77-93.

3 O'Connor indicates, "Byron gives the impression of having read Cuvier in some detail. He knew that the ideas of extinction, of the vast age of the earth, and even that of the vastness of the universe, had great potential to disturb if explored in detail" (33).

4 Following the practice of the Monthly Review and Critical Review in the previous century, the Edinburgh Review frequently offered essays summarizing and commenting on contemporary geological debates (Porter 101).

5 Darwin's The Botanic Garden contains extensive footnotes concerning the geological theory of James Hutton.

6 See Byron's Letters and Journals, ed. Leslie A. Marchand, vol. 3 (London: John Murray, 1974) 44, 48. Davy later visited Byron in Ravenna during 1820. 